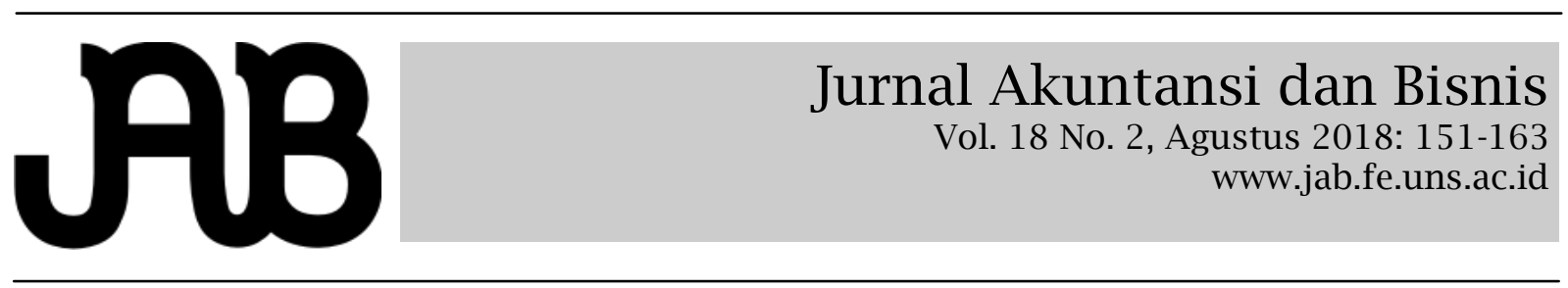

\title{
FENOMENA FLYPAPER EFFECT ATAS BELANJA DAERAH PEMERINTAH KABUPATEN/ KOTA DI PULAU BALI DAN NUSRA
}

WAKHID ANSORI ${ }^{1}$ (wakhid.ansori@gmail.com)
MUTHMAINAH $^{1}$ (muthmainah.ekis@gmail.com)

${ }^{1}$ Program Studi Akuntansi, Fakultas Ekonomi dan Bisnis, Universitas Sebelas Maret, Indonesia

\begin{abstract}
A B S T R A C T
The purpose of this research is to provide empirical evidence of the phenomenon of Flypaper Effect in Regency/Municipality that have the prime characteristics in tourism sector of Bali and Nusra during 2012-2016. Purposive sampling method was conducted for taking sampling and the samples that admission criteria were 187 samples. Testing data and hypotheses in this research with multiple regression analysis using IBM program Statistics Version 23. The results of this research indicate that the phenomenon of Flypaper Fffect occure in Regency/Municipality in Bali, and Nusra during 2012-2016. This is evident from the influence of Balancing Fund to the Local Government Expenditure is greater than the influence of the Local Own Revenue to the Local Government Expenditure.

Keywords: Flypaper Effect, Balancing Fund, Local Own Revenue, Local Government Expenditure
\end{abstract}

Penelitian ini bertujuan untuk memberikan bukti secara empiris ada tidaknya fenomena Flypaper Effect di Kabupaten/Kota yang memiliki karakteristik unggulan pada sektor pariwisata di Pulau Bali dan Nusra tahun 2012-2016. Metode purposive sampling dilakukan untuk pengambilan sampel dan jumlah sampel yang memenuhi kriteria sebanyak 187 sampel. Pengujian data dan hipotesis yang digunakan berupa analisis regresi berganda dengan menggunakan program IBM Statistics Version 23. Hasil pengujian dari penelitian ini menunjukkan bahwa fenomena Flypaper Effect terjadi pada Kabupaten/Kota di Pulau Bali dan Nusra tahun 2012-2016. Hal ini terlihat dari pengaruh Dana Perimbangan terhadap Belanja Daerah lebih besar daripada pengaruh PAD terhadap Belanja Daerah.

Kata kunci: Flypaper Effect, Dana Perimbangan, Pendapatan Asli Daerah, Belanja Daerah

\section{PENDAHULUAN}

Pada 1 Januari 2001 secara efektif mulai dilaksanakan kebijakan Otonomi Daerah dimana kebijakan tersebut dipandang memenuhi aspek desentralisasi yang sesungguhnya dan dianggap sangat demokratis (Maimunah, 2006). Dalam melaksanakan desentralisasi, setiap daerah otonom dituntut dapat menyelesaikan persoalan pemerintah daerahnya serta peran dana transfer pemerintah pusat juga tidak terhindarkan (Kusumadewi dan Rahman, 2007). Dengan adanya otonomi daerah berimplikasi pada kewenangan dan tanggungjawab daerah untuk memenuhi kebutuhan daerahnya masing-masing dan dalam pelaksanaannya didukung oleh perim- bangan keuangan pemerintah pusat dan daerah (UU No 33 Tahun 2004).

Berdasarkan UU No 9 Tahun 2015 tentang Pemerintahan Daerah dijelaskan bahwa dalam rangka kewenangan Pemerintah Daerah, dana transfer yang diberikan oleh Pemerintah Pusat berupa Dana Perimbangan yang terdiri dari DAU, DAK, dan DBH. Dijelaskan lebih lanjut dalam undang-undang tersebut bahwa selain Dana Perimbangan, Pemda memiliki sumber dana sendiri yaitu PAD, pembiayaan, dan lain-lain pendapatan serta pemerintah daerah diberikan kebijaksanaan dalam urusan penggunaan dananya.

Permasalahan pembiayaan pembangunan yang bersumber dari bantuan 
dana transfer adalah Pemda terlalu menggantungkan transfer pemerintah untuk membiayai belanja daerah dibanding mengoptimalkan potensi daerahnya (Armawaddin, 2015). Sebagaimana dijelaskan oleh Rokhaniyah dan Nugroho (2011) bahwa dana transfer bertujuan dalam meningkatkan kapasitas daerah untuk membiayai belanja daerah dengan penggalian sumber pembiayaan terutama dari fiskal daerah. Dalam Dana Perimbangan di Indonesia, DAU dikatagorikan sebagai block grant (besaran dananya ditentukan dengan formulasi tertentu), DAK sebagai special grant dan DBH sebagai revenue sharing (Kusumadewi dan Rahman, 2007).

Menurut Oates (1999) apabila Pemda merespon dana transfer dari pemerintah pusat lebih besar dibanding pendapatan daerahnya sendiri maka terjadi Flypaper Effect. Flypaper Effect merupakan kondisi keuangan Pemda dengan pembelanjaan lebih banyak menggantungkan dana transfer daripada dana Pemda sendiri (Mentayani, Hayati, dan Rusmanto, 2012).

Penelitian terkait Flypaper Effect telah dilakukan di berbagai negara. Penelitian di negara lain misalnya dilakukan oleh Cardenas dan Sharma (2011) meneliti fenomena Flypaper Effect di Meksiko dengan menggunakan data panel sebanyak 1.196 kota (sekitar 48\% jumlah kota) selama tahun 1993-2005 dan menghasilkan simpulan telah terjadi Flypaper Effect di Meksiko. Penelitian ini serupa dengan penelitian Deller, Maher dan Lledo (2007) dengan meneliti fenomena Flypaper Effect di Wisconsin, Amerika Serikat dan menghasilkan simpulan telah terjadi Flypaper Effect dengan hasil bahwa Pemerintah Daerah (local governments) di Wisconsin memiliki ketergantungan lebih tinggi pada Pemerintah (state) dalam belanja operasionalnya.

Penelitian empiris terkait Flypaper Effect juga telah dilakukan di berbagai daerah di Indonesia. Pengaruh DAU dan PAD terhadap BD di Pulau Sumatera telah diteliti dan menghasilkan simpulan bahwa telah terjadi Flypaper Effect (Maimunah, 2006). Penelitian Maimunah tersebut serupa dilakukan oleh Kusumadewi dan Rahman (2007) dengan menggunakan sampel 225
Kabupaten/Kota di Indonesia selama tahun 2001-2004.

Mentayani, dkk (2012) melakukan penelitian Flypaper Effect di Kabupaten/ Kota di Provinsi Kalimantan Selatan tahun 2010 dan hasilnya berbeda dengan peneliti lainnya, yaitu tidak terjadi Flypaper Effect. Hediyanto dan Rahayu (2016) meneliti fenomena Flypaper Effect di Kota Bandung selama tahun 2008-2012 dengan hasil tidak terjadi Flypaper Effect. Hasil penelitian tersebut sesuai dengan penelitian Kang dan Setyawan (2012) dengan menggunakan data cross section dari 188 Kabupaten/Kota di Indonesia selama tahun 2006-2008 dan dengan menggunakan data panel dari 484 Kabupaten/Kota selama tahun 2001-2008.

Hasil penelitian terdahulu tersebut tidak bisa digeneralisasi untuk daerah lainnya di Indonesia dikarenakan setiap daerah memiliki karakteristik yang berbeda dari berbagai aspek, baik dari aspek ekonomi, demografi dan kondisi geografinya. Penelitian ini merupakan replikasi dan pengembangan dari penelitianpenelitian terdahulu dengan perbedaan yaitu Pertama, menambahkan variabel independen yang digunakan. Penelitian sebelumnya rata-rata menggunakan variabel independen berupa DAU dan PAD sedangkan penelitian ini variabel independen yang digunakan adalah DAU, DAK, DBH, dan PAD. Penelitian ini menggunakan data time series pada Kabupaten/Kota yang memiliki sektor unggulan dalam bidang pariwisata yaitu Pulau Bali dan Nusra selama tahun 2012-2016.

Maimunah (2006), Kusumadewi dan Rahman (2007), dan Laksono dan Subowo (2014) memberikan simpulan bahwa DAU berpengaruh positif terhadap BD. Di sisi lain, Hediyanto dan Rahayu (2014) memberikan simpulan bahwa DAU berpengaruh positif namun tidak signifikan terhadap BD.

Laksono dan Subowo (2014) memberikan simpulan bahwa DAK berpengaruh positif terhadap BD. Sebaliknya, Listiorini (2012) memberikan simpulan bahwa DAK berpengaruh negatif terhadap BD. Di sisi lain, Nurdini, Wiratno, dan Farida (2014), memberikan simpulan bahwa DAK tidak berpengaruh terhadap BD. 
Nurdini, dkk (2014) memberikan simpulan bahwa DBH berpengaruh positif terhadap BD. Sebaliknya, Santoso, Suparta, dan Saimul (2015) menghasilkan simpulan bahwa DBH berpengaruh negatif terhadap BD. Di sisi lain, Listiorini (2012) menghasilkan simpulan bahwa DBH tidak berpengaruh terhadap BD.

Kusumadewi dan Rahman (2007), Mentayani, dkk (2012), Nurdini, dkk (2014), dan Hediyanto dan Rahayu (2016) memberikan simpulan bahwa PAD berpengaruh positif terhadap BD. Di sisi lain, Maimunah (2006) memberikan simpulan bahwa PAD berpengaruh positif namun tidak signifikan terhadap BD.

Sampel penelitian ini adalah Kabupaten/ Kota di Pulau Bali dan Nusra dengan data selama tahun 2012-2016. Nusra merupakan singkatan dari Nusa Tenggara dan terdiri dari dua daerah administratif yaitu Nusa Tenggara Barat (NTB) dan Nusa Tenggara Timur (NTT). Alasan menggunakan obyek penelitian ini karena Pulau Bali dan Nusra memiliki karakteristik berbeda dengan daerah lain di Indonesia khususnya pada sektor pariwisata. Pariwisata di Bali dan Nusra didukung dengan potensi dan sumber daya alam serta budaya Bali, NTB dan NTT, dan dalam beberapa tahun terakhir ditandai dengan pengakuan internasional dari berbagai lembaga internasional seperti Pulau Wisata Terbaik di Dunia (2005) dari majalah TIME, Pulau Wisata Asia Terbaik (2009) dari CEI Asia Magazine, Pulau Tujuan Wisata Terbaik di Asia Pasifik (2007, 2009, 2010), dan World's Best Halal Honeymoon Destination dan World's Best Halal Tourism Destination dalam ajang The World Halal Travel Summit \& Exhibition (2015). Selanjutnya Farouk (2016) menyatakan bahwa Bali, NTB, dan NTT telah mencapai pertumbuhan ekonomi luar biasa di akhir tahun 2015 dan kondisi tersebut memberikan deskripsi bahwa sektor pariwisata memberikan kontribusi pendapatan daerah bagi tiga provinsi tersebut.

Ahmar, Nurlinda, dan Muhani (2012) telah melakukan penelitian terkait peranan sektor pariwisata dalam peningkatkan PAD menghasilkan simpulan bahwa retribusi pariwisata berpengaruh positif terhadap
PAD. Dengan potensi pariwisata dan sumber daya alam yang dimiliki Pulau Bali dan Nusra maka akan mendongkrak PAD ketiga wilayah tersebut karena mengalami pertumbuhan pariwisata yang signifikan, artinya kemungkinan kecenderungan kepada Pemerintah Pusat terhadap Dana Perimbangan juga semakin kecil atau dengan kata lain Kabupaten/Kota di Pulau Bali dan Nusra kemungkinan tidak mengalami fenomena Flypaper Effect.

Fokus utama penelitian ini adalah untuk memberikan bukti empiris ada tidaknya fenomena Flypaper Effect dengan menguji pengaruh Dana Perimbangan dan PAD terhadap Belanja Daerah pada Pemerintah Kabupaten/Kota di Pulau Bali dan Nusra. Dengan perbedaan lingkup pemerintah daerah yang diambil, penelitian ini diharapkan dapat memberikan gambaran fenomena Flypaper Effect di Pulau Bali dan Nusra yang memiliki perbedaan karakteristik dengan daerah lain di Indonesia khususnya pada sektor pariwisata. Karakteristik tersebut membuat peneliti tertarik untuk meneliti ada tidaknya fenomena Flypaper Effect pada Kabupaten/ Kota di Pulau Bali dan Nusra selama tahun 2012-2016.

Adapun yang menjadi tujuan dalam penelitian ini adalah memberikan bukti empiris pengaruh DAU, DAK, DBH, dan PAD terhadap Belanja Daerah dan memberikan bukti empiris mengenai Fenomena Flypaper Effect terjadi pada Kabupaten/Kota di Pulau Bali dan Nusra.

\section{TINJAUAN PUSTAKA DAN PENGEM- BANGAN HIPOTESIS}

Penelitian ini berdasarkan pada teori keagenan (agency theory) yaitu pola hubungan antara agent dan principal. Jensen dan Meckling (1976) menerangkan hubungan keagenan merupakan sebuah perjanjian yang terjadi antara satu pihak (principal) dengan pihak lain (agent) dimana pihak lain tersebut sesuai kewenangannya bertindak dalam mewakili kepentingan principal dalam pengambilan keputusan. Anthony dan Govindarajan (2007:530) menyebutkan bahwa teori keagenan mengasumsikan bahwa principal dan agent masing-masing mempunyai preferensi atau tujuan yang 
berbeda.

Laksono dan Subowo (2014) menyatakan bahwa teori keagenan memandang bahwa Pemda bertindak selaku agen masyarakat akan bertindak sesuai dengan tugas yang diberikan oleh masyarakat (principal). Nurdini, dkk (2014) menambahkan bahwa salah satu wujud nyata dari hubungan agen dan prinsipal adalah desentralisasi, termasuk desentralisasi fiskal.

Dalam Permendagri No 13 Tahun 2006 disebutkan dasar pengelolaan keuangan daerah dalam masa satu tahun anggaran mulai dari 1 Januari sampai dengan 31 Desember terwujud dalam APBD. Selanjutnya dalam Permendagri tersebut dijelaskan bahwa dalam menyusun APBD disesuaikan dengan kebutuhan pemerintah daerah dan kemampuan pendapatan daerahnya. Menurut PP No 58 Tahun 2005 tentang Pengelolaan Keuangan Daerah disebutkan bahwa APBD merupakan satu kesatuan yang terdiri dari Pendapatan Daerah, Belanja Daerah, dan Pembiayaan Daerah serta pendapatan suatu daerah terdiri atas PAD, Dana Perimbangan, dan Lain-lain pendapatan daerah yang sah.

\section{Pengembangan Hipotesis Pengaruh Dana} Alokasi Umum Terhadap Belanja Daerah

UU No 33 Tahun 2004 menyebutkan bahwa DAU digunakan untuk mencapai tujuan desentralisasi dengan pemerataan kemampuan daerah dan bersumber dari pendapatan APBN. Dalam undang-undang tersebut disebutkan bahwa jumlah total DAU ditetapkan minimal 26\% dari Pendapatan Dalam Negeri Neto yang ditetapkan dalam APBN dan penentuan jumlah DAU suatu daerah pengalokasiannya dilakukan berdasarkan celah fiskal dan alokasi dasar.

Berdasarkan PP No 55 Tahun 2005 tentang Dana Perimbangan disebutkan bahwa penentuan Proporsi DAU antara Pemerintah Provinsi dan Kabupaten/Kota dihitung dengan formulasi tertentu dan diperoleh dari bobot urusan pemerintahan Provinsi dibandingan dengan Kabupaten/ Kota. Dijelaskan lebih lanjut dalam Peraturan Pemerintah tersebut apabila penentuan proporsinya belum dapat ditentukan secara kuantitatif, maka DAU ditetapkan dengan proporsi 10\% untuk Provinsi dan
90\% untuk Kabupaten/Kota.

Maimunah (2006), Kusumadewi dan Rahman (2007), dan Laksono dan Subowo (2014) memberikan simpulan bahwa DAU berpengaruh positif terhadap BD. Di sisi lain, Hediyanto dan Rahayu (2014) memberikan simpulan bahwa DAU berpengaruh positif namun tidak signifikan terhadap BD.

Penelitian ini mengajukan hipotesis DAU berpengaruh positif terhadap Belanja Daerah. Hal ini dikarenakan semakin besarnya nilai DAU yang diterima dari Pemerintah Pusat maka Pemerintah Daerah memiliki dana lebih dalam melakukan pengeluaran melalui Belanja Daerah.

H1 : Dana Alokasi Umum berpengaruh positif terhadap Belanja Daerah

\section{Pengaruh Dana Alokasi Khusus Terhadap Belanja Daerah}

UU No 33 Tahun 2004 dan PP No 55 Tahun 2005 menyebutkan bahwa DAK diberikan kepada suatu daerah tertentu untuk membantu mendanai kegiatan tertentu daerah sesuai dengan pentunjuk juknisnya dan disesuaikan dengan prioritas nasional serta bersumber dari pendapatan APBN. Selanjutnya dalam undang-undang tersebut disebutkan bahwa daerah yang menerima DAK dalam APBD nya harus menganggarkan Dana Pendamping DAK minimal 10\% dari jumlah alokasi DAK yang diterima.

Laksono dan Subowo (2014) memberikan simpulan bahwa DAK berpengaruh positif terhadap BD. Sebaliknya, Listiorini (2012) memberikan simpulan bahwa DAK berpengaruh negatif terhadap BD. Di sisi lain, Nurdini, Wiratno, dan Farida (2014), memberikan simpulan bahwa DAK tidak berpengaruh terhadap BD.

Penelitian ini mengajukan hipotesis DAK berpengaruh positif terhadap Belanja Daerah. Hal ini dikarenakan semakin besarnya nilai DAK yang diterima dari Pemerintah Pusat maka Pemerintah Daerah memiliki dana lebih dalam melakukan pengeluaran melalui Belanja Daerah.

H2 : Dana Alokasi Khusus berpengaruh positif terhadap Belanja Daerah

Pengaruh Dana Bagi Hasil Terhadap Belanja Daerah 
UU No 23 Tahun 2014 stdd UU No 9 Tahun 2015 menyebutkan bahwa DBH bersumber dari pendapatan tertentu APBN yang diberikan kepada daerah penghasil dengan alokasi yang ditentukan dengan formulasi persentase tertentu dan bertujuan mengurangi ketimpangan kemampuan keuangan Pemerintah Pusat dan Daerah. Selanjutnya dalam undang-undang tersebut dijelaskan bahwa DBH bersumber dari Pajak, Cukai dan Sumber Daya Alam.

Nurdini, dkk (2014) memberikan simpulan bahwa DBH berpengaruh positif terhadap BD. Sebaliknya, Santoso, Suparta, dan Saimul (2015) menghasilkan simpulan bahwa DBH berpengaruh negatif terhadap BD. Di sisi lain, Listiorini (2012) menghasilkan simpulan bahwa DBH tidak berpengaruh terhadap BD.

Penelitian ini mengajukan hipotesis DBH berpengaruh positif terhadap Belanja Daerah. Hal ini dikarenakan semakin besarnya nilai DBH yang diterima dari Pemerintah Pusat maka Pemerintah Daerah memiliki dana lebih dalam melakukan pengeluaran melalui Belanja Daerah.

H3 : Dana Bagi Hasil berpengaruh positif terhadap Belanja Daerah

\section{Pengaruh Pendapatan Asli Daerah Ter- hadap Belanja Daerah}

UU No 33 Tahun 2004 menyebutkan bahwa PAD bersumber dari pajak daerah, retribusi daerah, hasil pengelolaan kekayaan daerah yang dipisahkan dan lain-lain PAD yang sah dan dalam pemungutannya berdasarkan Peraturan Daerah dan tidak menyalahi peraturan perundang-undangan di Indonesia.

Kusumadewi dan Rahman (2007), Mentayani, dkk (2012), Nurdini, dkk (2014), dan Hediyanto dan Rahayu (2016) memberikan simpulan bahwa PAD berpengaruh positif terhadap BD. Di sisi lain, Maimunah (2006) memberikan simpulan bahwa PAD berpengaruh positif namun tidak signifikan terhadap BD.

Penelitian ini mengajukan hipotesis PAD berpengaruh positif terhadap Belanja Daerah. Hal ini dikarenakan semakin besarnya nilai PAD yang dimiliki oleh Daerah maka Pemerintah Daerah memiliki dana lebih dalam melakukan pengeluaran melalui Belanja Daerah.
H4 : Pendapatan Asli Daerah berpengaruh positif terhadap Belanja Daerah

\section{Fenomena Flypaper Effect}

Menurut Oates (1999) apabila Pemda merespon dana transfer dari pemerintah pusat lebih besar dibanding pendapatan daerahnya sendiri maka terjadi Flypaper Effect. Kusumadewi dan Rahman (2007) menyatakan bahwa terdapat beberapa penelitian mengenai perilaku Pemda dalam merespon transfer Pemerintah Pusat menghasilkan simpulan bahwa terjadi perbedaan perilaku Pemda dalam merespon transfer dan pendapatan daerahnya.

Maimunah (2006) memberikan simpulan bahwa Kabupaten/Kota di Pulau Sumatera mengalami fenomena Flypaper Effect. Deller, dkk (2007) menyatakan Pemerintah Daerah di Wisconsin, Amerika Serikat mengalami fenomena Flypaper Effect. Cardenas dan Sharma (2011) memberikan simpulan serupa bahwa terjadi fenomena Flypaper Effect di Meksiko. Di sisi lain, Mentayani, dkk (2012) memberikan simpulan bahwa Kabupaten/ Kota di Kalimantan Selatan tidak mengalami Flypaper Effect. Selanjutnya Hediyanto dan Rahayu (2016) memberikan simpulan bahwa Kota Bandung tidak mengalami fenomena Flypaper Effect terbukti dengan pengaruh DAU terhadap BD lebih kecil daripada pengaruh PAD terhadap BD. Hasil penelitianpenelitian yang dilakukan tersebut tidak dapat digeneralisasi untuk daerah lainnya di Indonesia karena setiap daerah memiliki karakteristik yang berbeda dari berbagai aspek, baik dari segi ekonomi, demografi dan kondisi geografinya.

Penelitian ini mengajukan hipotesis fenomena Flypaper Effect tidak terjadi pada Kabupaten/Kota di Pulau Bali dan Nusra. Hal ini dikarenakan dengan potensi pariwisata dan sumber daya alam yang dimiliki Pulau Bali dan Nusra maka akan mendongkrak PAD ketiga wilayah tersebut karena mengalami pertumbuhan pariwisata yang signifikan, artinya kemungkinan kecenderungan kepada Pemerintah Pusat terhadap Dana Perimbangan juga semakin kecil atau dengan kata lain tidak terjadi fenomena Flypaper Effect. 
Fenomena Flypaper Effect atas Belanja Daerah Pemerintah Kabupaten/Kota di Pulau Balidan Nusra (Ansori dan Muthmainah)

H5 : Fenomena Flypaper Effect tidak terjadi pada Kabupaten/Kota di Pulau Bali dan Nusra

Berdasarkan tinjauan pustaka dan pengembangan hipotesis diatas maka kerangka pemikiran dalam penelitian ini disajikan dalam gambar 1 .

\section{METODE PENELITIAN}

\section{Teknik Analisis Data}

Penelitian ini merupakan penelitian dengan pengujian hipotesis dan merupakan penelitian kuantitatif dengan data sekunder. Ruang lingkup penelitian dibatasi pada pengaruh DAU, DAK, DBH, dan PAD terhadap BD. Objek dalam penelitian ini adalah Kabupaten/Kota di Pulau Bali dan Nusra dengan periode yang digunakan tahun 2012-2016. Metode analisis data menggunakan metode statistik regresi berganda yang bertujuan untuk menilai ketergantungan variabel dependen terhadap variabel independennya.

\section{Populasi dan Sampel}

Populasi dalam penelitian ini adalah seluruh Kabupaten/Kota di Pulau Bali, dan Nusra yang terdiri dari 37 Kabupaten dan 4 Kota dengan data DAU, DAK, DBH, PAD, dan Belanja Daerah selama tahun 20122016. Sampel yang diambil dalam penelitian ini adalah Kabupaten/Kota di Pulau Bali, dan Nusra yang tidak mengala- mi pemekaran selama tahun 2012-2016. Alasan pemilihan sampel ini karena Kabupaten/Kota di Pulau Bali dan Nusra memiliki karakteristik yang berbeda dengan daerah lain di Indonesia khususnya pada sektor Pariwisata. Pariwisata di Bali dan Nusra didukung dengan potensi dan sumber daya alam serta budaya Bali, NTB dan NTT. Dengan potensi pariwisata dan sumber daya alam yang dimiliki oleh Pulau Bali dan Nusra maka akan mendongkrak PAD ketiga wilayah tersebut karena mengalami pertumbuhan pariwisata yang signifikan, artinya kemungkinan kecenderungan kepada Pemerintah Pusat terhadap Dana Perimbangan juga semakin kecil atau dengan kata lain tidak terjadi fenomena Flypaper Effect pada Kabupaten/Kota di Pulau Bali dan Nusra. Karakteristik tersebut membuat peneliti tertarik untuk meneliti ada tidaknya fenomena Flypaper Effect pada Kabupaten/Kota di Pulau Bali dan Nusra selama tahun 2012-2016.

Berdasarkan Laporan Keuangan Pemerintah Daerah yang telah diaudit oleh Badan Pemeriksa Keuangan Republik Indonesia menunjukkan bahwa sektor pariwisata Bali dan Nusra memberikan kontribusi pada Pendapatan Asli Daerah mencapai 65,34 persen. Tingginya pertumbuhan pariwisata berdampak langsung pada kabupaten/kota yang memiliki lokasi potensial wisata. World Wide Fund for Na-

Gambar 1.

Kerangka Pemikiran

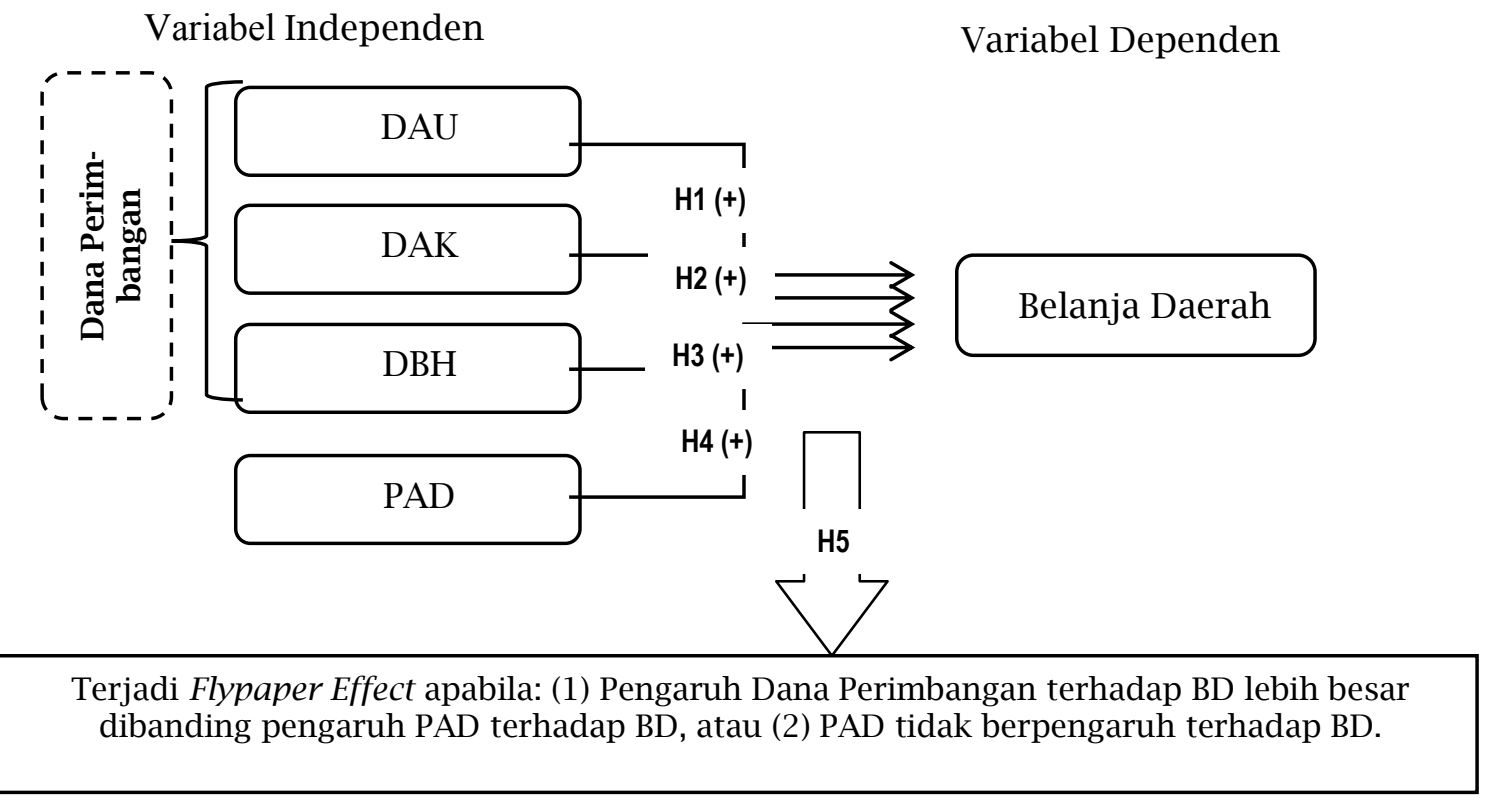


ture (WWF) Indonesia, sebuah organisasi non pemerintah internasional yang menangani masalah konservasi, penelitian dan restorasi lingkungan mengemukakan pemasukan APBD dari sektor pariwisata mencapai 1 triliun rupiah per tahun dengan adanya Pulau Komodo. Agung (2012) mengemukakan bahwa 76,19 persen Pendapatan Asli Daerah kabupaten terkaya di Bali berasal dari sektor pariwisata. Sjamsu (2013) menyatakan bahwa sektor pariwisata dari tiga gili terbesar di Lombok memberikan kontribusi mencapai 70 persen Pendapatan Asli Daerah. Selanjutnya menurut Farouk (2016) bahwa Bali, NTB, dan NTT telah mencapai pertumbuhan ekonomi luar biasa di akhir tahun 2015 dan kondisi tersebut memberikan gambaran bahwa sektor pariwisata telah memberikan kontribusi pendapatan daerah bagi tiga provinsi tersebut.

Pengambilan sampel penelitian ini dengan teknik purposive sampling berdasarkan kriteria yang ditentukan oleh peneliti yaitu sebagai berikut:

1. Kabupaten/Kota di Pulau Bali, dan Nusra yang tidak mengalami pemekaran dalam kurun waktu 2012-2016. Apabila data dari Kabupaten/Kota pemekaran dimasukkan sebagai sampel dimungkinkan dapat mengganggu generalisasi hasil penelitian karena ketergantungan terhadap Dana Perimbangan dari Pemerintah Pusat kemungkinan masih tinggi.

2. Kabupaten/Kota di Pulau Bali, dan Nusra yang mempublikasikan Laporan Keuangan berupa Laporan Realisasi Anggaran secara konsisten dalam kurun waktu 2012-2016 sehingga memiliki ketersediaan data pada situs Direktorat Jenderal Perimbangan Keuangan RI ataupun LHP atas LKPD Kabupaten/Kota oleh BPK RI.

Penelitian ini merupakan replikasi dan pengembangan dari penelitianpenelitian terdahulu dengan perbedaanyaitu, Pertama menambahkan variabel independen yang digunakan. Penelitian sebelumnya rata-rata menggunakan variabel independen berupa DAU dan PAD sedangkan penelitian ini variabel independen yang digunakan adalah DAU, DAK, DBH dan PAD. Kedua, Penelitian ini menggunakan data time series pada Kabupaten/Kota yang memiliki sektor unggulan dalam bidang pariwisata yaitu Pulau Bali dan Nusra selama tahun 2012-2016.

Sekaran dan Bougie (2016:316) menyebutkan bahwa pengujian hipotesis dilakukan dengan menggunakan analisis regresi linear berganda, karena terdapat lebih dari satu variabel independen untuk menjelaskan varian dalam variabel dependen. Penelitian ini menggunakan program IBM SPSS Statistics Version 23 untuk menganalisis data dan menguji hipotesisnya. Model yang digunakan berupa Model Regresi Linier Berganda (Multiple Linier Regression Model) dengan bentuk persamaan model regresi sebagai berikut:

$$
\mathbf{Y}=\boldsymbol{\alpha}+\boldsymbol{\beta}_{1} \mathbf{X}_{1}+\boldsymbol{\beta}_{2} \mathbf{X}_{2}+\boldsymbol{\beta}_{3} \mathbf{X}_{3}+\boldsymbol{\beta}_{4} \mathbf{X}_{4}+\varepsilon
$$

Keterangan :

Y: Belanja Daerah

$\alpha$ : Intercept (Konstanta)

$\beta_{1}-\beta_{4}$ : Slope (Koefisien Regresi)

$\mathrm{X}_{1}$ : Dana Alokasi Umum

$\mathrm{X}_{2}$ : Dana Alokasi Khusus

$\mathrm{X}_{3}$ : Dana Bagi Hasil

$\mathrm{X}_{4}$ : Pendapatan Asli Daerah

$\varepsilon$ : Error (Variabel Pengganggu)

Pengujian hipotesis penelitian dengan uji signifikan parameter individual (uji statistik t) pada tingkat keyakinan 95\% ( $\alpha=$ $5 \%)$. Selanjutnya untuk mendeteksi fenomena Flypaper Effect terdapat beberapa cara yang dijelaskan oleh beberapa peneliti sebelumnya. Cardenas dan Sharma (2011) memberikan tabel rujukan mengenai cara mengidentifikasi Flypaper Effect seperti yang dapat dilihat pada Tabel 1 .

Fenomena Flypaper Effect dapat dilihat dari koefisien dana perimbangan dibanding koefisien PAD. Koefisien dana perimbangan dapat diperoleh dari pen-

Tabel 1.

Flypaper Effect and Implication

\begin{tabular}{lcl}
\hline \multicolumn{1}{c}{ Condition } & Results & \multicolumn{1}{c}{ Implication } \\
\hline$\beta 1>\beta 2$ & & $\begin{array}{l}\text { unconditional } \\
\text { transfers increase }\end{array}$ \\
$\beta 1=$ koefisien & Flypaper & $\begin{array}{l}\text { spending more } \\
\text { than an equiva- } \\
\text { Transfers }\end{array}$ \\
$\beta 2=$ koefisien & Effect & $\begin{array}{l}\text { lent increase in } \\
\text { the private income }\end{array}$
\end{tabular}

Sumber : Cardenas dan Sharma (2011) 
jumlahan koefisien DAU, DAK dan DBH. Selanjutnya untuk melihat lebih jelas perbandingan pengaruh antara Dana Perimbangan dan Pendapatan Asli Daerah terhadap Belanja Daerah dapat dilihat pada hasil perbandingan nilai adjusted R Square. Simpulan diambil apabila nilai adjusted $\mathrm{R}$ Square hasil uji simultan variabel Dana Perimbangan terhadap belanja daerah lebih besar dibandingkan nilai R Square hasil uji parsial variabel PAD terhadap belanja daerah maka dapat dinyatakan telah terjadi Flypaper Effect (Maimunah, 2006).

Fenomena Flypaper Effect dapat dilihat dari koefisien dana perimbangan dibanding koefisien PAD. Koefisien dana perimbangan dapat diperoleh dari penjumlahan koefisien DAU, DAK dan DBH. Selanjutnya untuk melihat lebih jelas perbandingan pengaruh antara Dana Perimbangan dan Pendapatan Asli Daerah terhadap Belanja Daerah dapat dilihat pada hasil perbandingan nilai adjusted R Square. Simpulan diambil apabila nilai adjusted $\mathrm{R}$ Square hasil uji simultan variabel Dana Perimbangan terhadap belanja daerah lebih besar dibandingkan nilai R Square hasil uji parsial variabel PAD terhadap belanja daerah maka dapat dinyatakan telah terjadi Flypaper Effect (Maimunah, 2006).

\section{ANALISIS DAN PEMBAHASAN}

Objek penelitian ini terdiri dari 39 kabupaten dan 4 kota di Pulau Bali dan Nusra. Data yang digunakan berdasarkan realisasi DAU,
DAK, DBH, PAD, dan BD dari Kabupaten/ Kota tersebut selama kurun waktu 20122016. Penelitian ini menggunakan jumlah sampel sebanyak 187 observasi yang dijelaskan pada Tabel 2.

Dua kabupaten pemekaran tidak dimasukkan sebagai sampel yaitu Kabupaten Belu dan Kabupaten Malaka. Dengan total populasi 205 Pemerintah Kabupaten/Kota dikurangi 18 Pemerintah Kabupaten/Kota, maka jumlah sampel akhir yang diperoleh adalah 187 Pemerintah Kabupaten/Kota. Jumlah sampel tersebut sudah memenuhi jumlah minimum pengambilan sampel penelitian multivarian yang mensyaratkan jumlah sampel minimum sepuluh kali jumlah variabel dalam penelitiannya (Sekaran dan Bougie, 2014:269).

\section{Statistik Deskriptif}

Berdasarkan Tabel 3 diketahui bahwa variabel dependen berupa Belanja Daerah (BD) dan variabel independen yaitu DAU, DAK, $\mathrm{DBH}$, dan PAD serta jumlah sampel (N) penelitian sebanyak 187 observasi.

Rata-rata DAU sebesar Rp530.032,70 dengan standar deviasi DAU sebesar Rp175.043,19. Pemerintah Kabupaten/Kota dengan DAU terendah yaitu Kabupaten Sabu Raijua tahun 2012 sebesar Rp220.235,15. Sebaliknya, Pemerintah Kabupaten/ Kota dengan DAU tertinggi yaitu Kabupaten Lombok Timur tahun 2016 sebesar Rp1.162.763,21.

Rata-rata DAK sebesar Rp96.855,35

Tabel 2.

Data Pemilihan Sampel

\begin{tabular}{lrrrrrrr}
\hline \multicolumn{1}{c}{ Keterangan } & $\mathbf{2 0 1 2}$ & $\mathbf{2 0 1 3}$ & $\mathbf{2 0 1 4}$ & $\mathbf{2 0 1 5}$ & $\mathbf{2 0 1 6}$ & Jumlah \\
\hline Jumlah Populasi Pemerintah Kab. / Kota & 41 & 41 & 41 & 41 & 41 & 205 \\
Kab./Kota mengalami pemekaran & $(2)$ & $(2)$ & $(2)$ & $(2)$ & $(2)$ & $(10)$ \\
Data Outlier & $(2)$ & $(1)$ & $(1)$ & $(2)$ & $(2)$ & $(8)$ \\
Jumlah sampel akhir yang diperoleh & 37 & 38 & 38 & 37 & 37 & 187 \\
\hline
\end{tabular}

Tabel 3.

Statistik Deskriptif

\begin{tabular}{lrrrrr}
\hline & N & \multicolumn{1}{c}{ Minimum } & \multicolumn{1}{c}{ Maximum } & \multicolumn{1}{c}{ Mean } & \multicolumn{1}{c}{ Std. Dev. } \\
\hline DAU & 187 & $220.235,15$ & $1.162 .763,21$ & $530.032,70$ & $175.043,19$ \\
DAK & 187 & $5.226,19$ & $465.783,12$ & $96.855,35$ & $73.109,30$ \\
DBH & 187 & $6.838,71$ & $134.193,39$ & $28.813,68$ & $24.025,61$ \\
PAD & 187 & $9.316,62$ & $807.042,11$ & $104.181,67$ & $131.045,39$ \\
BD & 187 & $301.660,32$ & $2.200 .204,45$ & $885.526,55$ & $397.545,56$ \\
Valid N (listwise) & 187 & & & & \\
\hline
\end{tabular}

Keterangan : DAU, DAK, DBH, PAD dan BD dalam Jutaan Rupiah 
dengan standar deviasi DAK sebesar Rp73.109,30. Pemerintah Kabupaten/Kota dengan DAK terendah yaitu Kota Denpasar tahun 2015 sebesar Rp5.226,19. Sebaliknya, Pemerintah Kabupaten/ Kota dengan DAK tertinggi yaitu Kabupaten Lombok Timur tahun 2016 sebesar Rp465.783,12.

Rata-rata DBH sebesar Rp28.813,68 dengan standar deviasi DBH sebesar Rp24.025,61. Pemerintah Kabupaten/Kota dengan DBH terendah yaitu Kabupaten Sabu Raijua tahun 2015 sebesar Rp6.838,71. Sebaliknya, Pemerintah Kabupaten/Kota dengan DBH tertinggi yaitu Kota Denpasar tahun 2012 sebesar Rp134.193,39.

Rata-rata PAD sebesar Rp104.181,67 dengan standar deviasi PAD sebesar Rp131.045,39. Pemerintah Kabupaten/Kota dengan PAD terendah yaitu Kabupaten Sabu Raijua tahun 2012 sebesar Rp9.316,62. Sebaliknya, Pemerintah Kabupaten/Kota dengan PAD tertinggi yaitu Kota Denpasar tahun 2016 sebesar Rp807.042,11.

Rata-rata Belanja Daerah sebesar Rp885.526,55 dengan standar deviasi Belanja Daerah sebesar Rp397.545,56. Pemerintah Kabupaten/Kota dengan Belanja Daerah terendah yaitu Kabupaten Sabu Raijua tahun 2012 sebesar Rp301.660,32. Sebaliknya, Pemerintah Kabupaten/Kota dengan Belanja Daerah tertinggi yaitu Kabupaten Buleleng tahun 2016 sebesar Rp2.200.204,45.

\section{Analisis Hipotesis}

Pengujian hipotesis dalam penelitian ini dilakukan dengan uji signifikansi parameter individual (uji t). Pengujian ini dimaksudkan untuk mengidentifikasi apakah variabel independen secara individual/parsial berpengaruh terhadap variable dependennya. Pengambilan keputusan terjadi apabila asymp. sig kurang dari 0,05 maka variabel independen secara individual berpengaruh terhadap variabel dependennya. Sebaliknya, apabila asymp. sig lebih dari 0,05 maka variabel independen secara individual tidak berpengaruh terhadap variabel dependennya.

Berdasarkan Tabel 4 diperoleh kesimpulan bahwa setiap variabel DAU, DAK, DBH, dan PAD berpengaruh positif ter- hadap variabel Belanja Daerah pada tingkat signifikansi 0,05. Selanjutnya dengan hasil tersebut dapat diperoleh bentuk persamaan sebagai berikut:

$$
\begin{aligned}
\text { LnBD }= & 1,260+0,658 \text { LnDAU }+0,078 \\
& \text { LnDAK }+0,027 \text { LnDBH }+0,230 \\
& \text { LnPAD }+\mathrm{e}
\end{aligned}
$$

Nilai konstanta pada persamaan regresi berganda di atas sebesar 1,260 artinya apabila variabel belanja daerah (BD) tidak dipengaruhi oleh keempat variabel independennya atau apabila keempat variabel independennya (DAU, DAK, DBH, dan PAD) bernilai nol, maka besarnya belanja daerah akan bernilai 1,260. Koefisien regresi untuk keempat variabel independen (DAU, DAK, DBH, dan PAD) bernilai positif menunjukkan bahwa dalam penelitian ini terdapat hubungan searah antara DAU, DAK, DBH, dan PAD terhadap BD.

\section{Pembahasan}

Berdasarkan pengujian hipotesis pertama $\left(\mathrm{H}_{1}\right)$ secara statistik disimpulkan bahwa variabel DAU terbukti berpengaruh positif terhadap BD karena nilai signifikansinya di bawah 0,05. Hasil penelitian ini sesuai dengan penelitian Maimunah (2006), Kusumadewi dan Rahman (2007), dan Laksono dan Subowo (2014) dengan memberikan simpulan bahwa DAU berpengaruh positif terhadap BD. Penelitian ini telah berhasil membuktikan bahwa DAU berpengaruh positif terhadap belanja daerah, maka dari itu hipotesis pertama $\left(\mathrm{H}_{1}\right)$ diterima, artinya bahwa semakin besarnya nilai DAU yang diterima oleh Daerah maka Pemerintah Daerah memiliki dana lebih dalam melakukan pengeluaran melalui Belanja Daerah.

Tabel 4.

Uji Signifikansi Individual (Uji t)

\begin{tabular}{ccrc}
\hline Variabel & B & t-value & Sig \\
\hline (Constant) & 1,260 & 3,745 & 0,000 \\
LnDAU & 0,658 & 17,307 & 0,000 \\
LnDAK & 0,078 & 6,540 & 0,000 \\
LnDBH & 0,027 & 2,208 & 0,028 \\
LnPAD & 0,230 & 18,842 & 0,000 \\
\hline
\end{tabular}

Variabel Dependen : LnBD; Adj R²: 95.5\% 
Berdasarkan pengujian hipotesis kedua $\left(\mathrm{H}_{2}\right)$ secara statistik disimpulkan bahwa variabel DAK terbukti berpengaruh positif terhadap BD karena nilai signifikansinya di bawah 0,05 . Hasil penelitian ini sesuai dengan penelitian Laksono dan Subowo (2014) dengan memberikan simpulan bahwa DAK berpengaruh positif terhadap BD. Penelitian ini telah berhasil membuktikan bahwa DAK berpengaruh positif terhadap belanja daerah, maka dari itu hipotesis kedua $\left(\mathrm{H}_{2}\right)$ diterima, artinya bahwa semakin besarnya nilai DAK yang diterima oleh Daerah maka Pemerintah Daerah memiliki dana lebih dalam melakukan pengeluaran melalui Belanja Daerah.

Berdasarkan pengujian hipotesis ketiga $\left(\mathrm{H}_{3}\right)$ secara statistik disimpulkan bahwa variabel DBH terbukti berpengaruh positif terhadap BD karena nilai signifikansinya di bawah 0,05. Hasil penelitian ini sesuai dengan penelitian Nurdini, dkk (2014) dengan memberikan simpulan bahwa DBH berpengaruh positif terhadap BD. Penelitian ini telah berhasil membuktikan bahwa DBH berpengaruh positif terhadap belanja daerah, maka dari itu hipotesis ketiga $\left(\mathrm{H}_{3}\right)$ diterima, artinya bahwa semakin besarnya nilai DBH yang diterima oleh Daerah maka Pemerintah Daerah memiliki dana lebih dalam melakukan pengeluaran melalui Belanja Daerah.

DBH memberikan pengaruh positif terhadap BD, namun jika dibandingkan dengan DAU, DAK dan PAD dapat dilihat bahwa DBH memiliki kontribusi paling kecil. Hal tersebut terlihat dari koefisien persamaan regresi dimana DBH mempunyai koefisien terkecil yaitu sebesar 0,027, sedangkan DAU mempunyai koefisien terbesar sebesar 0,658, PAD dengan koefisien 0,230 dan DAK dengan koefisien 0,078. Artinya, jika Belanja Daerah naik satu satuan, DBH hanya berkontribusi sebesar 0,027 atau $2,7 \%$.

Berdasarkan pengujian hipotesis keempat $\left(\mathrm{H}_{4}\right)$ secara statistik disimpulkan bahwa variabel PAD terbukti berpengaruh positif terhadap Belanja Daerah karena nilai signifikansinya di bawah 0,05. Hasil penelitian ini sesuai dengan penelitian Kusumadewi dan Rahman (2007), Mentaya- ni, dkk (2012), Nurdini, dkk (2014), dan Hediyanto dan Rahayu (2016) dengan memberikan simpulan bahwa PAD berpengaruh positif terhadap BD. Penelitian ini telah berhasil membuktikan bahwa PAD berpengaruh positif terhadap belanja daerah, maka dari itu hipotesis keempat $\left(\mathrm{H}_{4}\right)$ diterima, artinya bahwa semakin besar nilai PAD suatu Daerah maka Pemerintah Daerah memiliki dana lebih dalam melakukan pengeluaran melalui Belanja Daerah.

Beberapa peneliti sebelumnya mendeteksi fenomena Flypaper Effect dengan beberapa cara diantaranya Cardenas dan Sharma (2011) memberikan tabel rujukan mengenai cara mengidentifikasi Flypaper Effect dengan membandingkan koefisien Dana Transfer dan Pendapatan Daerah. Berdasarkan persamaan regresi yang diperoleh dari uji signifikansi parameter individual (uji statistik t), koefisien dana perimbangan dapat diperoleh dari penjumlahan koefisien DAU, DAK dan DBH yaitu sebesar 0,763 , sedangkan nilai koefisien PAD adalah 0,230. Hasil yang didapat adalah Dana Perimbangan dan PAD berpengaruh positif dengan nilai koefisien dana Perimbangan lebih besar dari nilai koefisien PAD sebagaimana tersaji dalam tabel 5.

Berdasarkan tabel 5 diperoleh kesimpulan bahwa nilai Adjusted $R$ Square variabel Dana Perimbangan berpengaruh positif terhadap BD sebesar 86,9\%, sedangkan nilai $R$ Square variabel PAD berpengaruh positif terhadap BD sebesar 78\%. Hasil perbandingan tersebut terlihat bahwa pengaruh Dana Perimbangan terhadap Belanja Daerah lebih besar dibanding pengaruh PAD terhadap Belanja Daerah $(0,869>0,780)$. Berdasarkan hasil tersebut dapat disimpulkan bahwa Pemerintah Ka-

Tabel 5.

Nilai Koefisien Dana Perimbangan dan PAD

\begin{tabular}{lcc}
\hline \multicolumn{1}{c}{ Variabel } & $\begin{array}{c}\text { Jumlah } \\
\text { Nilai } \\
\text { Koef. }\end{array}$ & Adj. R \\
\hline Dana Perimbangan & 0,763 & 0,869 \\
PAD & 0,230 & 0,780 \\
\hline
\end{tabular}

Sumber : Data Sekunder Diolah (2018) 
bupaten/Kota di Pulau Bali dan Nusra tahun 2012-2016 lebih cenderung mengandalkan Dana Perimbangan (DAU, DAK dan DBH) dibandingkan dengan PAD untuk membiayai belanja daerahnya.

Berdasarkan hasil pada tabel 5 disimpulkan bahwa hipotesis kelima $\left(\mathrm{H}_{5}\right)$ ditolak atau dengan kata lain masih terjadi fenomena Flypaper Effect. Dengan karakteristik pariwisata dan sumber daya alam yang dimiliki ternyata fenomena Flypaper Effect masih terjadi pada Kabupaten/Kota di Pulau Bali dan Nusra selama kurun waktu tahun 2012-2016. Hal ini berarti pemerintah daerah masih memiliki pola ketergantungan yang tinggi atas dana perimbangan dari Pemerintah Pusat. PAD yang diperoleh Pemda belum mampu memberikan pengaruh besar pada belanja daerahnya sehingga pemerintah daerah harus terus meningkatkan kemandirian ekonomi dengan lebih giat lagi dalam mengoptimalkan PAD untuk mengurangi fenomena Flypaper Effect yang terjadi. Hasil penelitian ini konsisten dengan hasil penelitian Maimunah (2006), Deller, Maher dan Lledo (2007), Cardenas dan Sharma (2011).

\section{SIMPULAN DAN IMPLIKASI Simpulan}

Hasil analisis regresi berganda menghasilkan dua kesimpulan yaitu, Pertama, hasil pengujian hipotesis pertama, kedua, ketiga dan keempat diterima, artinya besarnya nilai DAU, DAK, DBH dan PAD secara simultan ataupun parsial berpengaruh positif terhadap besarnya nilai Belanja Daerah pada Kabupaten/Kota di Pulau Bali dan Nusra tahun 2012-2016. Dari keempat variabel independen, DAU memiliki pengaruh yang paling besar dalam pengeluaran belanja daerah, sedangkan DBH memiliki pengaruh paling kecil. Kedua, hasil pengujian dari hipotesis kelima membuktikan bahwa fenomena Flypaper Effect masih terjadi pada Kabupaten/ Kota di Pulau Bali dan Nusra yang memiliki karakteristik unggulan pada sektor pariwisata ini. Hal ini berarti respon Pemerintah Kabupaten/ Kota terhadap Dana Perimbangan (DAU, DAK dan DBH) lebih besar dibandingkan respon terhadap PAD dalam membiayai pengeluaran belanja dae- rahnya atau dengan kata lain pemerintah daerah memiliki ketergantungan yang masih tinggi kepada pemerintah pusat.

\section{Implikasi}

Penelitian ini menghasilkan implikasi teoritis bahwa Dana Perimbangan dan PAD berpengaruh positif terhadap BD dan terlihat bahwa teori keagenan berlaku dalam menganalisis fenomena Flypaper Effect pada Kabupaten/Kota di Pulau Bali dan Nusra selama tahun 2012-2016. Sedangkan implikasi praktis penelitian ini bermanfaat bagi beberapa pihak yaitu:

1. Bagi Pemerintah Pusat digunakan sebagai pertimbangan dalam mengambil kebijakan terkait pemberian Dana Perimbangan kepada Kabupaten/Kota di Pulau Bali dan Nusra dengan melihat fenomena Flypaper Effect yang terjadi serta dapat dijadikan masukan dalam penyusunan kebijakan pada masa mendatang terkait APBN dan APBD.

2. Bagi Pemerintah Daerah di Pulau Bali dan Nusra digunakan sebagai bahan kajian untuk meningkatkan kemandirian ekonomi daerahnya dengan lebih giat lagi dalam mengoptimalkan PAD melalui pariwisata untuk mengurangi fenomena Flypaper Effect yang terjadi.

3. Bagi masyarakat, dapat digunakan untuk mengawasi kegiatan pelayanan publik dan pertanggungjawaban APBD oleh Pemerintah Daerah di Pulau Bali dan Nusra.

\section{KETERBATASAN DAN SARAN Keterbatasan}

Penelitian ini memiliki dua keterbatasan yaitu, Pertama, belum menggunakan seluruh populasi sehingga hasilnya kemungkinan belum mencerminkan Kabupaten/ Kota yang tidak dijadikan sampel. Kedua, tahun yang digunakan sebagai data sampel terbatas pada kurun waktu 2012-2016 dan belum membedakan daerah yang memiliki PAD tinggi (kaya) dengan PAD rendah (miskin).

\section{Saran}

Berdasarkan keterbatasan penelitian dan kekurangan yang ada maka penelitian selanjutnya diharapkan dapat menggunakan 
seluruh populasi Kabupaten/Kota di Pulau Bali dan Nusra termasuk daerah yang mengalami pemekaran dan menambah lingkup tahun yang diteliti dan memisahkan daerah PAD tinggi dengan daerah PAD rendah sehingga dapat dilihat perbedaan Flypaper Effect yang terjadi. Analisis akan lebih dapat digeneralisasi jika data yang digunakan lebih banyak dan mewakili seluruh populasi.

\section{DAFTAR PUSTAKA}

Ahmar, Nurlinda, dan Muhani, M. (2012). Peranan sektor pariwisata dalam meningkatkan pendapatan asli daerah kota Palopo. Jurnal Equilibrium, 2 (1), 113-121.

Anthony, R. N., dan Govindarajan, V. (2007). Management Control Systems, Twelfth Edition. New York: McGrawHill.

Armawaddin, M. (2015). Analisis Flypaper Effect pada belanja daerah kabupaten/ kota di Sulawesi Tenggara. Jurnal Ekonomi Pembangunan, 18 (8), 13-19.

Bifel, H. (2017). Pariwisata NTT Jadi Andalan. Diakses dari https:// kupang.antaranews. com pada 20 Januari 2018.

Cardenas, O.J., dan Sharma, A. (2011). Mexican municipalities and the Flypaper Effect. Journal of Economic Literature, $77,1-16$.

CNN Indonesia. (2017). Bali Terima Penghargaan Destinasi Wisata Terbaik di Dunia. Diakses dari https://www. cnnindonesia. com pada 20 Januari 2018.

Deller, S., Maher, C., dan Lledo, V. (2007). Wisconsin local government, state shared revenues and the illusive Flypaper Effect. Journal of Public Budgeting, Accounting \& Financial Management, 19 (2), 200-220.

Ghozali, I. (2016). Aplikasi Analisis Multivariate Dengan Program SPSS, Edisi Kedelepan. Semarang: Badan Penerbit Universitas Diponegoro.

Hediyanto, L. dan Rahayu, S. (2014). Flypaper Effect pada dana alokasi umum dan pendapatan asli daerah terhadap belanja daerah pada kota bandung periode 2008-2012. e-Proceeding of Management, 1 (3), 338-348.

Jensen, M. C,. dan Meckling, W. H. (1976). Theory of the firm: managerial behavior, agency costs and ownership structure. Journal of Financial Economics, 3 (4), 305-360.
Kang, Y. dan Setyawan, D. (2012). Intergovernmental transfer and the Flypaper Effect - evidence from municipalities/ regencies in Indonesia. Working Paper. KDI School of Public Policy and Management. http://www. kdischool.ac.kr/ new/eng/faculty/working.jsp. May 14, 2012.

Kementerian Koordinator Bidang Perekonomian. 2011. Masterplan Percepatan dan Perluasan Pembangunan Ekonomi Indonesia (MP3EI) 2011-2025, Koridor Ekonomi Bali-Nusa Tenggara. Jakarta.

Kusumadewi, D.A. dan Rahman, A. (2007). Flypaper Effect pada dana alokasi umum (DAU) dan pendapatan asli daerah (PAD) terhadap belanja daerah pada kabupaten/kota di Indonesia. Jurnal Akuntansi dan Auditing Indonesia, 11 (1), 67-80.

Laksono, B.B. dan Subowo. (2014). Pengaruh pajak daerah, retribusi daerah, DAU dan DAK terhadap belanja daerah. Accounting Analysis Journal, 3 (4), $\quad 457-465 . \quad$ http:// journal.unnes.ac.id/sju/index. php / aaj. November, 2014. ISSN 2252-6765.

Listiorini. (2012). Fenomena Flypaper Effect pada dana perimbangan dan pendapatan asli daerah terhadap belanja daerah pada kabupaten/kota di Sumatera Utara. Jurnal Keuangan dan Bisnis, 4 (2), 111-126.

Maimunah, M. 2006. Flypaper Effect pada dana alokasi umum (DAU) dan pendapatan asli daerah (PAD) terhadap belanja daerah pada kabupaten/kota di pulau Sumatera. Jurnal Simposium $\mathrm{Na}$ sional Akuntansi IX, Padang. 1-27.

Mentayani, I., Hayati, N., dan Rusmanto. (2012). Flypaper Effect pada dana alokasi umum dan pendapatan asli daerah terhadap belanja daerah pada kota dan kabupaten di propinsi Kalimantan Selatan. Jurnal Spread, 2 (1), 55-64.

Nurdini, R., Wiratno, A., dan Farida, Y.N. (2014). Analisis Flypaper Effect pada dana alokasi umum (DAU), dana alokasi khusus (DAK), dana bagi hasil (DBH), dan pendapatan asli daerah (PAD) terhadap belanja daerah (BD) kabupaten/kota di Jawa Barat. Jurnal Akuntansi dan Keuangan, 1 (1), 79-92. ISSN : $2356-2706$.

Oates, W. E. (1999). An Essay of Fiscal Federalism. Journal of Economics Literature, 37 (3), 1120-1149.

Republik Indonesia. Peraturan Menteri Dalam Negeri RI Nomor 13 Tahun 2006. Pedoman Pengelolaan Keuangan Dae- 
rah. 15 Mei 2006. Jakarta.

Republik Indonesia. Peraturan Menteri Dalam Negeri RI Nomor 21 Tahun 2011. Perubahan Kedua atas Permendagri No. 13 Tahun 2006 tentang Pedoman Pengelolaan Keuangan Daerah. 25 Mei 2011. Jakarta.

Republik Indonesia. Undang-Undang RI Nomor 32 Tahun 2004. Pemerintahan Daerah. 15 Oktober 2004. Lembaran Negara RI Tahun 2004 Nomor 125. Sekretariat Negara. Jakarta.

Republik Indonesia. Undang-Undang RI Nomor 33 Tahun 2004. Perimbangan Keuangan antara Pemerintah Pusat dan Pemerintahan Daerah. 15 Oktober 2004. Lembaran Negara RI Tahun 2004 Nomor 126. Sekretariat Negara. Jakarta.

Republik Indonesia. Undang-Undang RI Nomor 23 Tahun 2014. Pemerintahan Daerah. 2 Oktober 2014. Lembaran Negara RI Tahun 2014 Nomor 244. Sekretariat Negara. Jakarta.

Republik Indonesia. Undang-Undang RI Nomor 9 Tahun 2015. Perubahan Kedua atas UU Nomor 23 Tahun 2014 tentang Pemerintahan Daerah. 18 Maret 2015. Lembaran Negara RI Tahun 2015 Nomor 58. Sekretariat Negara. Jakarta.

Republik Indonesia. Peraturan Pemerintah RI Nomor 55 Tahun 2005. Dana Perimbangan. 9 Desember 2005. Lem- baran Negara RI Tahun 2005 Nomor 137. Sekretariat Negara. Jakarta.

Republik Indonesia. Peraturan Pemerintah RI Nomor 58 Tahun 2005. Pengelolaan Keuangan Daerah. 9 Desember 2005. Lembaran Negara RI Tahun 2005 Nomor 140. Sekretariat Negara. Jakarta.

Rismawan, I. (2016). Pertumbuhan Ekonomi Bali dan Nusa Tenggara Kategori Luar Biasa. Tribunnews, 29 Februari 2016.

Rokhaniyah, S., dan Nugroho, M.R. (2011). Analisis flypaper effect pada belanja pemerintah kota dan kabupaten di Indonesia tahun 2006-2008. Jurnal Fokus Ekonomi, 10 (2), 100-113. Santoso, I., Suparta, I.W., dan Saimul. (2015). Flypaper Effect pada pengelolaan keuangan daerah di provinsi Lampung. Jurnal Ekonomi Pembangunan, 4 (2), 135-166.

Sekaran, U., dan Bougie, R. (2016). Research Methods for Bussiness. A skill Building Approac; Seventh Edition. USA: Wiley and Sons Ltd.

Setyo, S. (2016). Pariwisata NTB Sabet Tiga Penghargaan Internasional. Diakses dari https://www.radarlombok.co.id pada 20 Januari 2018.

Sugiyono dan Susanto, A. (2015). Cara Mudah Belajar SPSS \& LISREL, Teori dan Aplikasi untuk Analisis Data Penelitian. Bandung: Penerbit Alfabeta. 